Annals of Plant and Soil Research 22(4): 354-360(2020)

https://doi.org/10.47815/apsr.2020.10004

\title{
Uptake kinetics of nitrogen, phosphorus and potassium in fennel (Foeniculumvulgare) with nitrogen input
}

\author{
N. SHARMA, B.L. JATAND O.P. AISHWATH \\ Bhagwant University, Sikar Road, Ajmer-305 004, Rajasthan, India \\ ${ }^{1}$ ICAR-National Research Centre on Seed Spices, Tabiji-305206, Ajmer, Rajasthan
}

Received: August, 2020; Revised accepted, September, 2020

\begin{abstract}
Field experiments were carried out on sandy loam soil of TypicHaplustepts with various nitrogen levels i.e. 40, 60, 80, 100 and $120 \mathrm{~kg} \mathrm{ha}^{-1}$ during Ravi seasons of 2015-17. These treatments were compared with control and absolute control to calculate uptake kinetics. Results revealed thatnitrogen uptake rate increased with increase in doses of $N$, however it was highest with $120 \mathrm{~kg} \mathrm{~N} \mathrm{ha}^{-1}$. During 91-120 days followed the linear trend with increased doses of $N$ and also somewhat 61-90. Uptake rate of $N$ at 121-180 days also followed the similar trend as that of 91-120 days up to $80 \mathrm{~kg} \mathrm{~N}$ ha $a^{-1}$ thereafter reduced with higher levels of $\mathrm{N}$. Hence, the uptake rate reduced with higher doses of $N$ and age of crop plant or nearer to maturity. Phosphorus uptake rate was increased sharply at 100 and $120 \mathrm{~kg} \mathrm{~N}^{-1}$ during 0-60 and 121-180 days. During 61-90, 91-120 and 121180 days, $P$ uptake rate was increased linearly with increased doses of $N$ levels. In general, potassium uptake rate increased linearly with increase in time and doses of $\mathrm{N}$, however it was increased exponentially at $120 \mathrm{~kg} \mathrm{~N}$ during 121-180 days. Moreover, $K$ uptake was lower at lower levels of $N$ during 121-180 days in comparison to 91-120 days. Overall uptake rate of $N, P$ and $K$ was more with higher doses of $N$, and duration and age of crop plants. However, $N$ and $K$ uptake rate was highest at 91-120 days and reduced thereafter. Moreover, the uptake rate of $K$ was higher than $N$ and was least of $P$. Hence, $K$ accumulation was highest and $P$ was least among the major nutrients. Whereas, $N, P$ and $K$ uptake rate was positively influenced by $N$ input up to the age of120 days of fennel. Therefore, it can be concluded that higher doses of $N$ and age of crop plants has negative relation for the uptake of $N$, whereas $P$ uptake rate gave a positive relation with higher doses of $N$ and aging of crop plants. In contrast to $N$ and $P, K$ uptake rate shown positive relation to $N$ input and negative at highest levels of $N$.
\end{abstract}

Key words: Ajmer fennel-1, nutrients, nitrogen, uptake kinetics, yield.

\section{INTRODUCTION}

Study of uptake kinetics of nutrients in crop plant is a very important to determines the uptake rate of nutrients with time and this relies upon a wide variety of factors, consisting of plant species and their varieties, environmental conditions, soil properties, nutrients supply and interrelationship amongst nutrient and soil microorganisms, their affiliation with plant roots etc. This determines the need of nutrients during crop growing period at specific time. Crop production point of view, uptake kinetics is very necessary for nutrients requirements of plant, productivity and growth kinetics. Uptake kinetics and growth kinetics are dynamic and interdependent processes, optimizes the nutrient supply toobtain desirable yield. Any imbalance in matching the nutrient supply to the demand of the plant can reduce growth and increase the incidence of nutrient disorders or the accumulation of potentially harmful elements in edible tissues. Furthermore, it can extend needless build-up of nutrients in the soil. However, the most suitable nutrient supply solely be accomplished when the plant nutrient uptake is precisely predicted. Nutrient uptake kinetics is the mechanism by which plants capture essential nutrient for their growth and development. A series of chemical and biochemical processes take place inside a plant which govern via these elements directly or indirectly for synthesis and breakdown of organic compounds. As the uptake rate of nitrogen is closely related to plant growth, the quantification of nitrogen uptake rate is strongly dependent on plant dry matter accumulation. In most of plants nitrogen uptake models use either the limited dry weight data measured at intervals during the experiments, or employ an empirical approach (Silberbush and Lieth, 2004) to calculate plant growth rate. Fennel (Foeniculumvulgare Mill.) is an important seed spice crop in India. It is widely 
cultivated throughout the temperate and subtropical region. It accumulates huge biomass demands more nutrients than any other seed spices with very long crop duration (210-240 days). Being a very important crop, there is no information available on nutrient uptake kinetics with respect to $\mathrm{N}$ supply. However, studies are available on mineral content in fennel with respect to biological, medicinal and dietary purpose, particularly for functions in living organisms (Singh and Garg, 2006; Demirelet al., 2008; Barros, 2010) Uptake pattern of nutrients in fennel was worked by Aishwath, (2017) and growth kinetics in coriander with lime (Aishwathet al., 2015). Based on the above information, none of the work is available on uptake kinetics. Therefore, present investigation was carried out to assess the nutrients uptake and their uptake rate of fennel withand without nitrogen input.

\section{MATERIALS AND METHODS}

Field experiments were carried outduring Rabi season of 2015-2016 and 20162017 at ICAR-National Research Centre on Seed Spices, Tabiji, Ajmer, Rajasthan, India. This was laid between $74^{\circ} 35^{\prime} 39^{\prime \prime}$ to $74^{\circ} 36^{\prime} 01^{\prime \prime} \mathrm{E}$ longitude and on $26^{\circ} 22^{\prime} 12^{\prime \prime}$ to $26^{\circ} 22^{\prime} 31^{\prime \prime} \mathrm{N}$ latitude. Climate of the Ajmer area characterized as semi-arid. The average annual rainfall of the area is $536 \mathrm{~mm}$ and most of it (85-90\%) receives from June to September. July and August are most rainy months contributing $60.0 \%$ of the average rainfall. Soil moisture control section remains dry for more than 90 cumulative days and hence moisture regime classified as Ustic. Mean annual temperature is 24.5 to $25.0^{\circ} \mathrm{C}$. January is the coolest month of the season and temperature remains around $7.0^{\circ} \mathrm{C}$. Sometimes, frost is also occurring in this month. During October-November, day and night temperature variation remains greatly wide. There were five levels of $N$ i.e., 40,60, 80, 100 and $120 \mathrm{~kg} \mathrm{ha}^{-1}$ and these were compared with control (without nitrogen with basal doses of other nutrients) and absolute control (without any nutrients input). These treatments were arranged in a randomized block design with three replications. Seeds of the crop (Ajmer Fennel-1)were sown during mid of October in the $50 \mathrm{~cm}$ line to line apart and distance from plant to plant was maintained at $15 \mathrm{~cm}$. Cultural practices were uniformly followed during the growing seasons in both the years. The crop was harvested in mid of April when seeds matured. After harvest, seeds were separated from the straw by beating of bundles thereafter winnowing.Plant samples were collected at various growth stages i.e. 60 , 90, 120 and 180 days. Root and shoot parts were washed with tap water and then $0.1 \mathrm{M} \mathrm{HCl}$ followed by deionized water. After air dry, plant samples were dried in oven at $70^{\circ} \mathrm{C}$ till the constant weight obtained. When the samples were properly dried and then took the dry weight.Nitrogen was determined byMicro Kjeldahl method (Jackson, 1973). Phosphorus and $\mathrm{K}$ contents were estimated from digested samples by vanado-molybdo yellow colour method and by flame photometer (Jackson, 1973), respectively.Plant samples were collected at various growth interval ie. 60, 90, 120 and 180 days to caculate the dry matter accumulation in per unit time.

Nutrients uptake rate with time $\left(\mathrm{ng} \mathrm{s}^{-1}\right)=\frac{\text { Nutrients accumulation at particular stage }}{\mathrm{T}_{\text {ime taken to accumulation of that nutrients }}}$

The data obtained during both the years were pooled and analyzed by ANOVA and treatment differences were expressed for Least Significant Differences (LSD) at $5 \%$ probability to determine the significance among the treatment means (Cochran and Cox, 1987).

\section{RESULTS AND DISCUSSION}

\section{Biomass accumulation, Nitrogen uptake and its kinetics}

Biomass accumulation and nitrogen uptake increased with increased levels of $\mathrm{N}$ (Table 1). However, it was highest at $120 \mathrm{~kg} \mathrm{~N}$ $\mathrm{ha}^{-1}$. During 60 days, the uptake was more at 40 and $100 \mathrm{~kg} \mathrm{~N}$ ha $^{-1}$ over their proc eeding levels, whereas uptake was higher with 40,60 and 100 $\mathrm{kg} \mathrm{N}^{-1}$ at 90 days and la st two stages. It is obvious that higher $\mathrm{N}$ input improved the more rhizospheric $\mathrm{N}$ and early taken up more by the crop from the abundanceas reported by Aishwath, (2004) in Withaniasomnifera. Uptake was more with each successive levels of $\mathrm{N}$ (Fig. 1). Irrespective of $N$ input, the uptake of $N$ was increased exponentialy at later growth stages 
Table 1: N, P and K Uptake (mg plant ${ }^{-1}$ ) by fennel with applied doses of $\mathrm{N}$

\begin{tabular}{|c|c|c|c|c|c|c|c|c|c|c|c|c|c|c|c|c|}
\hline \multirow{2}{*}{ Treatment } & \multicolumn{4}{|c|}{ Dry matter accumulation (g plant ${ }^{-1}$ ) } & \multicolumn{4}{|c|}{$\mathrm{N}$ uptake (at days) } & \multicolumn{4}{|c|}{ P uptake (at days) } & \multicolumn{4}{|c|}{ K uptake (at days) } \\
\hline & 60 & 90 & 120 & 180 & 60 & 90 & 120 & 180 & 60 & 90 & 120 & 180 & 60 & 90 & 120 & 180 \\
\hline Control & 1.3 & 13.3 & 59.9 & 126.8 & 3.3 & 20.9 & 65.6 & 118.4 & 0.6 & 3.3 & 12.5 & 24.1 & 4.4 & 25.2 & 76.1 & 134.3 \\
\hline NO & 1.6 & 14.2 & 68.4 & 141.5 & 4.7 & 24.4 & 80.5 & 143.6 & 0.8 & 3.7 & 14.8 & 30.7 & 5.4 & 27.6 & 90.3 & 159.2 \\
\hline N40 & 1.9 & 17.1 & 77.5 & 147.0 & 5.9 & 29.9 & 95.3 & 180.8 & 1.0 & 4.4 & 17.6 & 31.9 & 6.5 & 35.6 & 105.7 & 177.9 \\
\hline N60 & 1.9 & 19.5 & 82.8 & 165.2 & 5.8 & 35.4 & 108.3 & 227.7 & 1.0 & 5.3 & 19.1 & 40.2 & 6.5 & 41.3 & 114.7 & 210.0 \\
\hline N80 & 2.0 & 21.2 & 89.8 & 174.7 & 6.3 & 39.6 & 118.0 & 232.8 & 1.0 & 5.8 & 21.6 & 42.1 & 7.0 & 46.5 & 127.0 & 228.1 \\
\hline N100 & 2.4 & 25.6 & 97.9 & 182.0 & 7.8 & 47.8 & 133.6 & 245.5 & 1.2 & 7.2 & 24.3 & 45.0 & 8.8 & 58.0 & 139.5 & 251.9 \\
\hline N120 & 2.4 & 26.3 & 108.0 & 195.9 & 8.4 & 51.6 & 158.3 & 281.1 & 1.3 & 7.6 & 27.6 & 65.7 & 9.1 & 60.4 & 157.3 & 347.8 \\
\hline CD at $5 \%$ & 0.3 & 2.4 & 3.5 & 5.0 & 1.1 & 4.6 & 7.4 & 11.8 & 0.1 & 0.7 & 1.2 & 2.5 & 1.0 & 5.6 & 6.0 & 7.6 \\
\hline
\end{tabular}

At days: Growth stages of crop during sampling

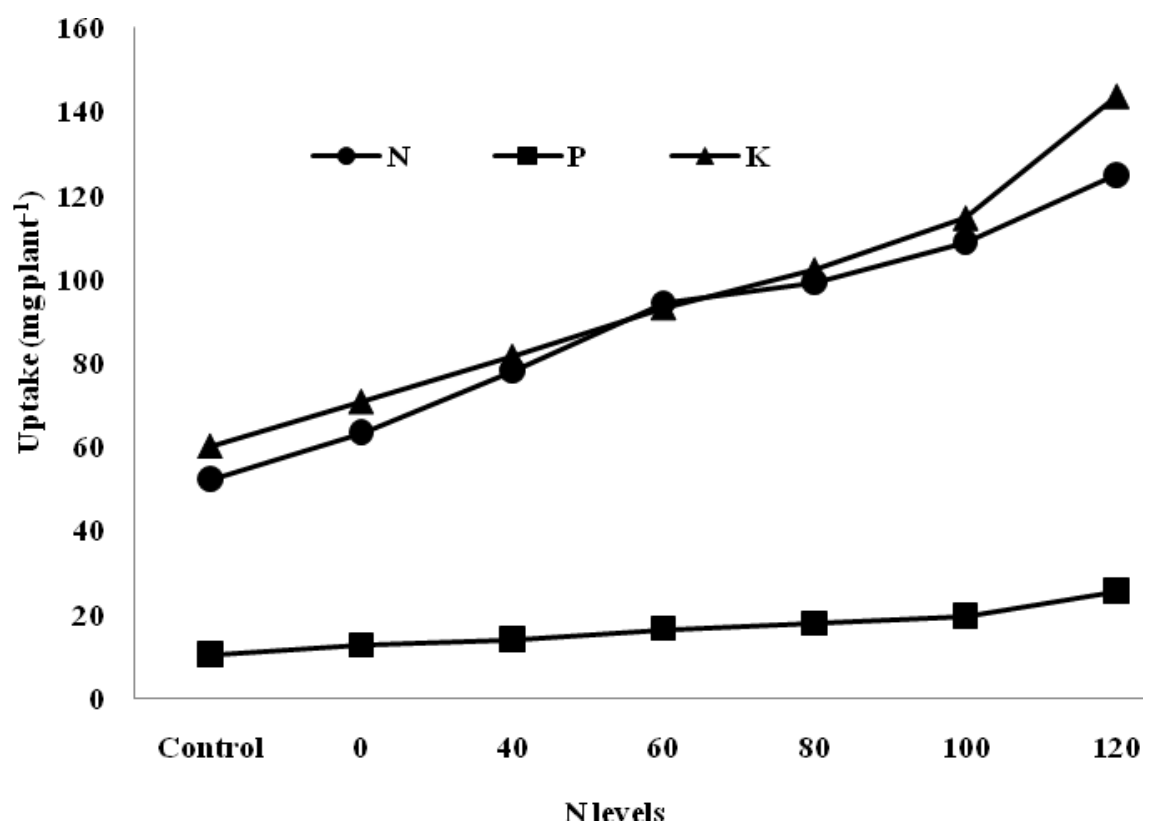

Fig. 1: Irrespective of days, N, P and $\mathrm{K}$ uptake $\left(\mathrm{mg} \mathrm{plant}^{-1}\right)$ in fennel

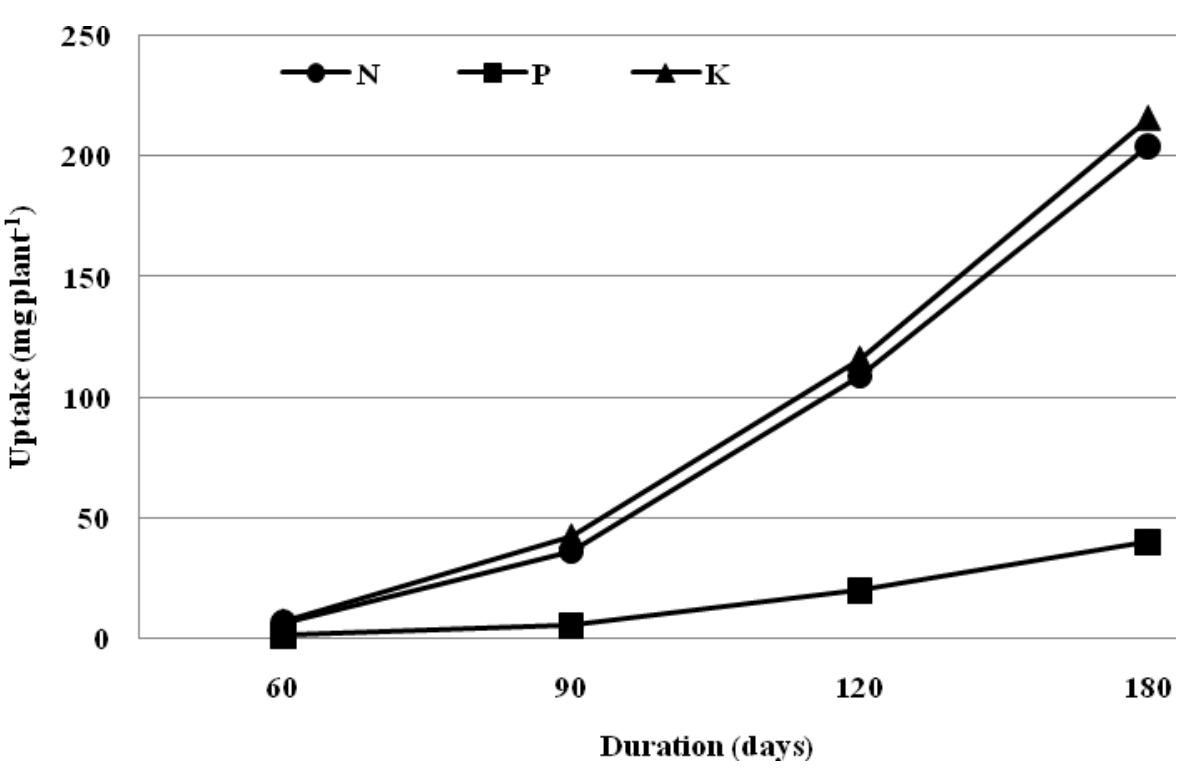

Fig. 2: Irrespective of $\mathrm{N}$ input, N, $\mathrm{P}$ and $\mathrm{K}$ uptake $\left(\mathrm{mg} \mathrm{plant}^{-1}\right)$ in fennel 
Fig. 2). This might be due to higher accumulation of biomass and also more content in biomass resultant more accumulation of nitrogen in later growth stages(Sharma andAishwath, 2018),they have reported higher biomass accumulation at later growth stages in fennel. The nitrogen uptake rate was highest with $120 \mathrm{~kg} \mathrm{~N} \mathrm{ha}^{-1}$ at all the growth stages(Fig. 3).

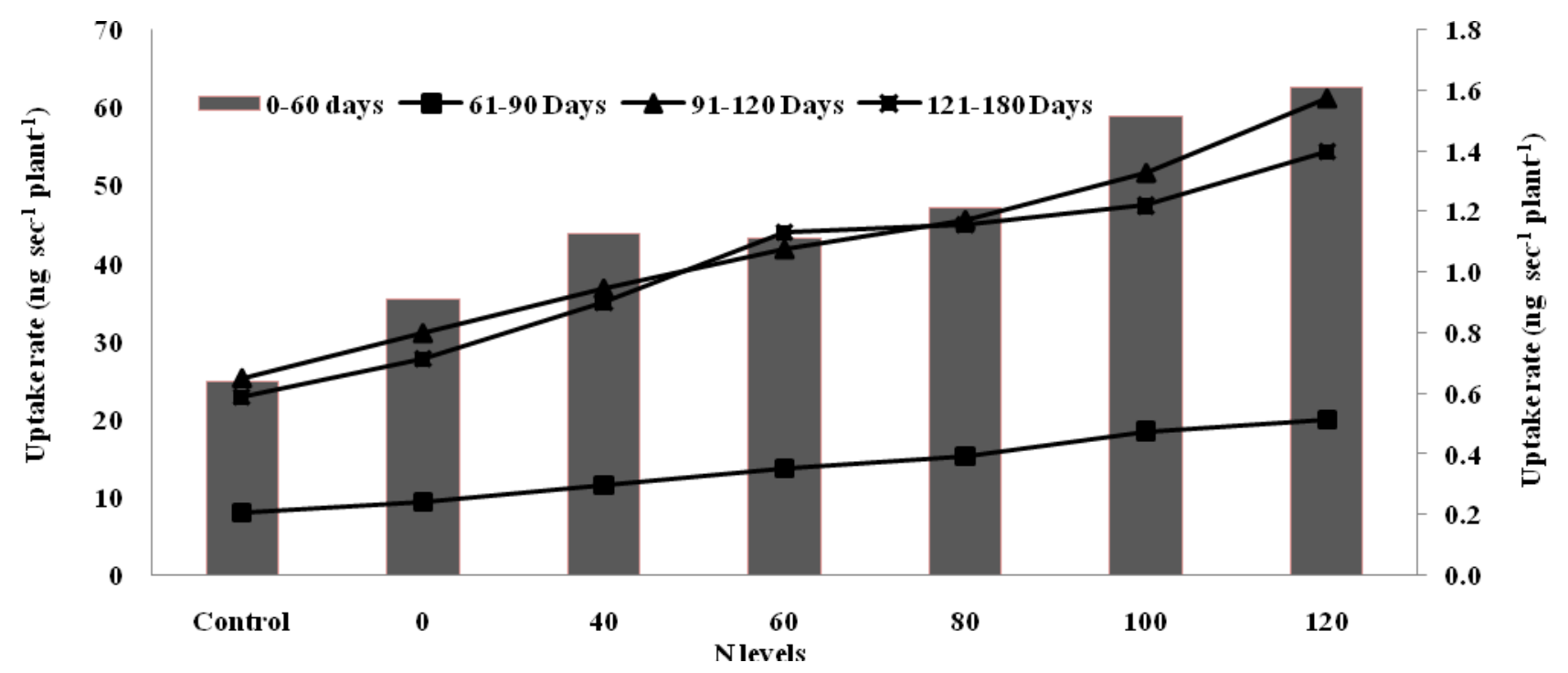

Fig. 3: $\mathrm{N}$ uptake rate $\left(\mathrm{ng} \mathrm{sec}{ }^{-1}\right.$ plant $\left.^{-1}\right)$ in fennel with $\mathrm{N}$ inputs

It was also more with all $\mathrm{N}$ levels as compared to control and absolute control. This is because of higher input of $\mathrm{N}$ enhanced higher biomass and content in plant.Raiet al., (2002), also reported that uptake of $\mathrm{N}$ increased with only at higher levels of $\mathrm{N}$. Irrespective of $\mathrm{N}$ input, uptake rate of $\mathrm{N}$ was more at later growth stages (61-90, 91-120 and 121-180 days) as compared to initial growth stage of crop (0-60 days). The average uptake rate was $1.16 \mathrm{ng} \mathrm{s}^{-1}$ plant $^{-1}$ at 0 60 days. Uptake rate followed the linear trend with increased doses of Nduring 61-90 and 91120 days. Nitrogen uptake rate was 8.6 times higher at $61-90$ days than $0-60$ days. Uptake rate of $\mathrm{N}$ at 121-180 days also followed the similar trend as that of $91-120$ days up to $80 \mathrm{~kg}$ $\mathrm{N} \mathrm{ha}^{-1}$ thereafter reduced with higher levels of $\mathrm{N}$. Hence, the uptake rate was more with higher doses of $\mathrm{N}$ at early growth stages and uptake rate of crop plants declined at later growth stages or nearer to maturity. This is because of plant nearer to attaining maturity experienced senescence, which reduces biomass accumulation rate as well as absorption of nutrient from soil (Sharma andAishwath, 2018).

\section{Phosphorus Uptake and its kinetics}

Phosphorous uptake was highest at 120 $\mathrm{kg} \mathrm{N} \mathrm{ha}^{-1}$ and lowest at lower level of $\mathrm{N}$ at all the growth stages of crop (Table 1). At most of stages $(90,120$ and 180 days), uptake of $P$ enhanced positivly with graded doses of applied $\mathrm{N}$ (Fig.1).Irrespective of $\mathrm{N}$ input, the $\mathrm{P}$ uptake was increased linearly in all growth stages(Fig.

2).More the supply of $\mathrm{N}$ resulted more of protein synthesis in plants requires more of energy through ATPs encourages more uptake of $P$ and accordingly accumulation with higher doses of $\mathrm{N}$ (Daniel et al., 1998).Phosphorus uptake rate was increased sharply at 100 and $120 \mathrm{~kg} \mathrm{~N}^{-}$ ${ }^{1}$ during $0-60$ and $121-180$ days (Fig. 4). During 61-90, 91-120 and 121-180 days, $P$ uptake rate was increased linearly with increased $\mathrm{N}$ levels, which was 11, 40 and 41 times higher over 0-60 days, respectively. Hence, $\mathrm{P}$ uptake rate was higher with higher doses of $\mathrm{N}$ and also later age of crop plants. More $\mathrm{N}$ input encouraged the more $\mathrm{N}$ accumulation in fennel tissues, hence uptake rate of $P$ was more with higher doses of $\mathrm{N}$. Fennel is an herbaceous perennial bushy plant, therefore root growth remains active even after senescence of herbaceous aerial parts. Being a immobile nutrient $(P)$, its absorption depends on reach of roots to the available $P$ at soil site. Hence more root growth at later stage accessed more of $P$ resulted more $P$ uptake rate nearer to maturity (Sharma and Aishwath, 2018). 


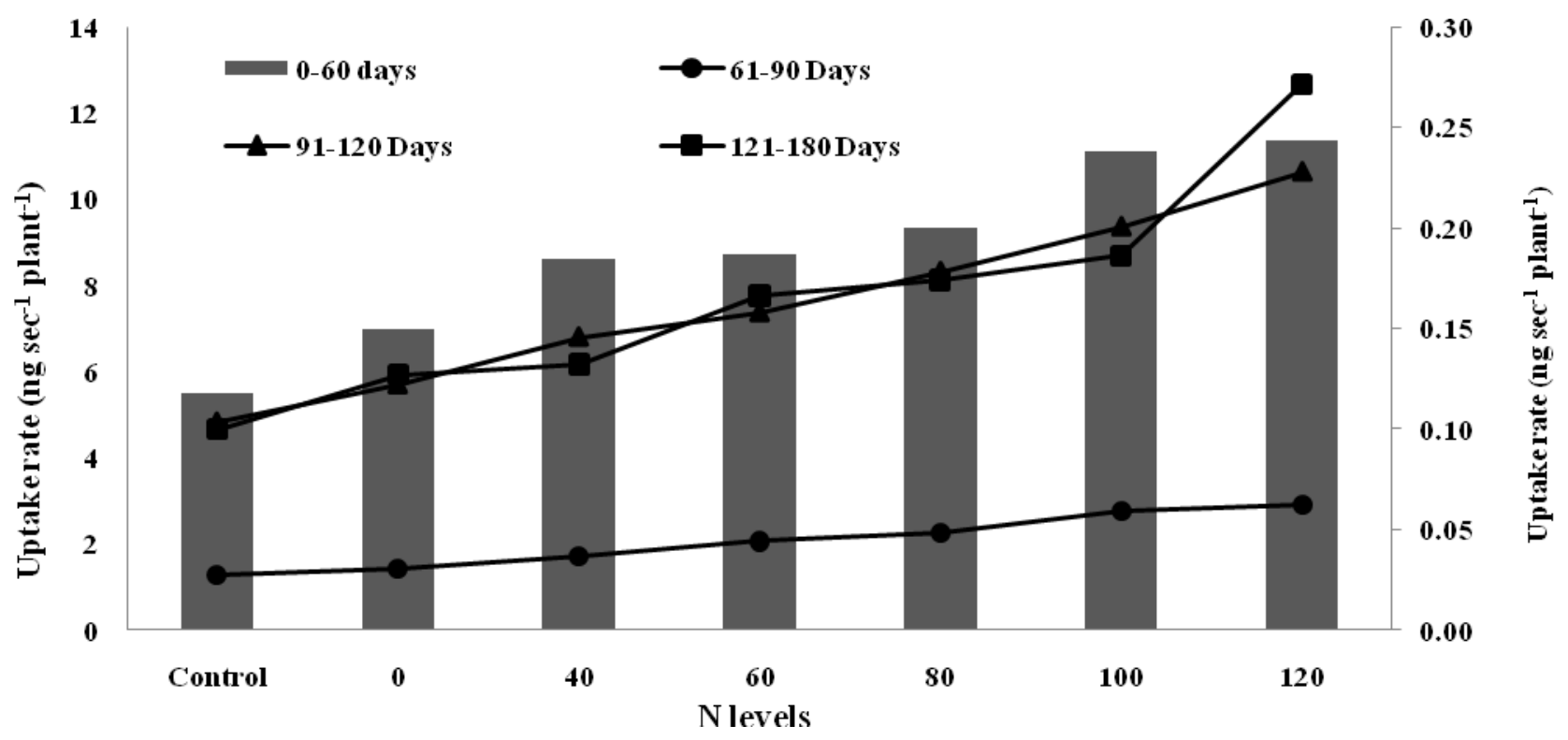

Fig. 4: $\mathrm{N}$ uptake rate $\left(\mathrm{ng} \mathrm{sec}{ }^{-1}\right.$ plant $\left.^{-1}\right)$ in fennel with $\mathrm{N}$ inputs

\section{Potassium uptake and its kinetics}

Potassium uptake was increased in all successive levels of $N$ (Table 1).During 60 days, higher uptake was observed in all $\mathrm{N}$ levels except $40 \mathrm{~kg} \mathrm{~N} \mathrm{ha}^{-1}$. Likewise, Kuptake was also enhanced with $\mathrm{N}$ at 90, 120 and 180 days (Fig. 1). Irrespective of $N$ input, the Kuptake was increased exponentialyat later growth stages
(Fig. 2). Higher $\mathrm{N}$ application in soil forms the potassium nitrate with its $(\mathrm{K})$ abundance which is highly mobile in soil and well distributed in root zone of crop provides the greater opportunities for absorption by the plants root, hence more uptake by the plant. More biomass accumulation at later growth stages leads to more uptake at later stages.

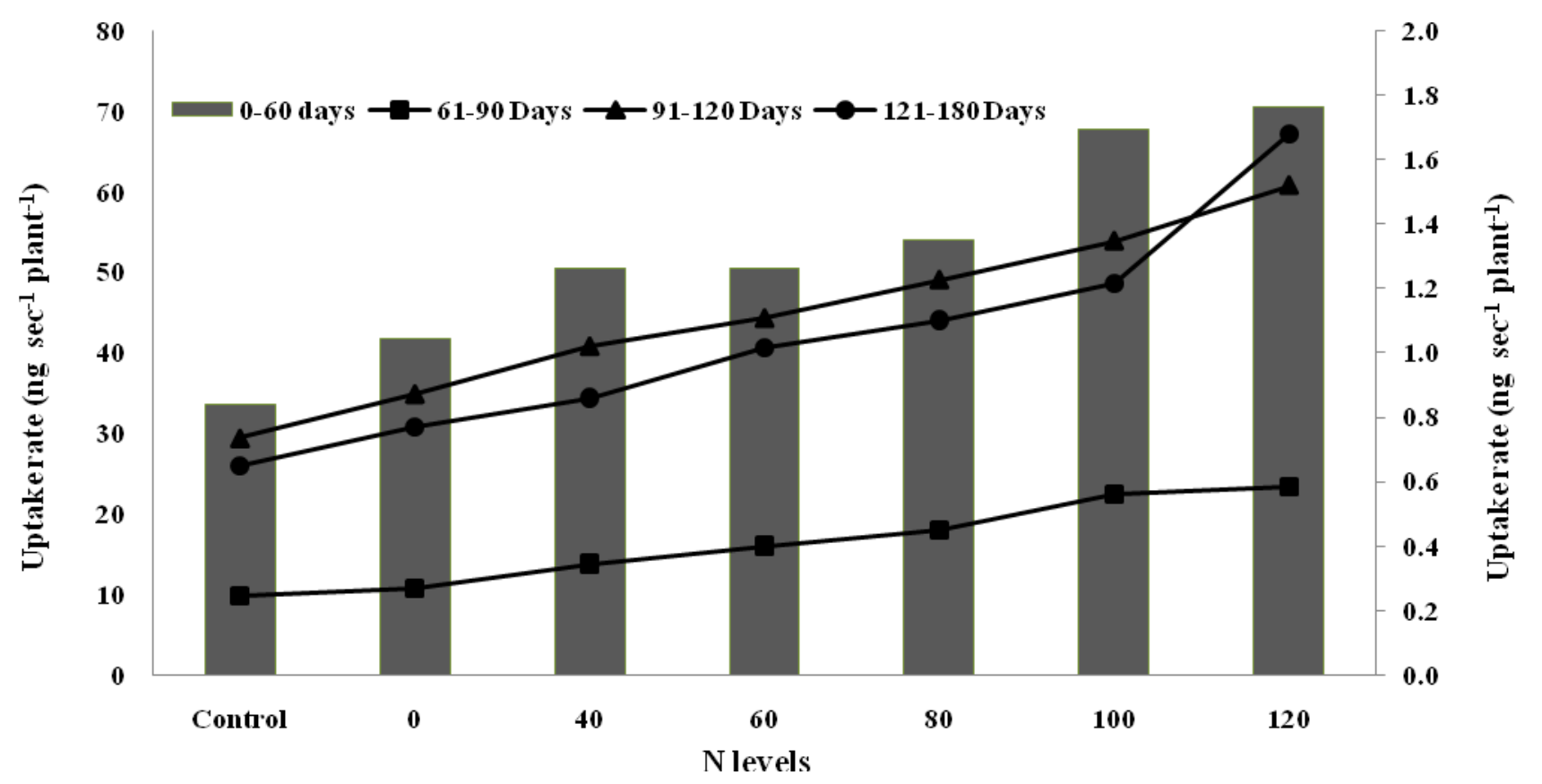

Fig.5: $\mathrm{P}$ uptake rate $\left(\mathrm{ng} \mathrm{sec}{ }^{-1}\right.$ plant $\left.^{-1}\right)$ in fennel with $\mathrm{N}$ inputs 


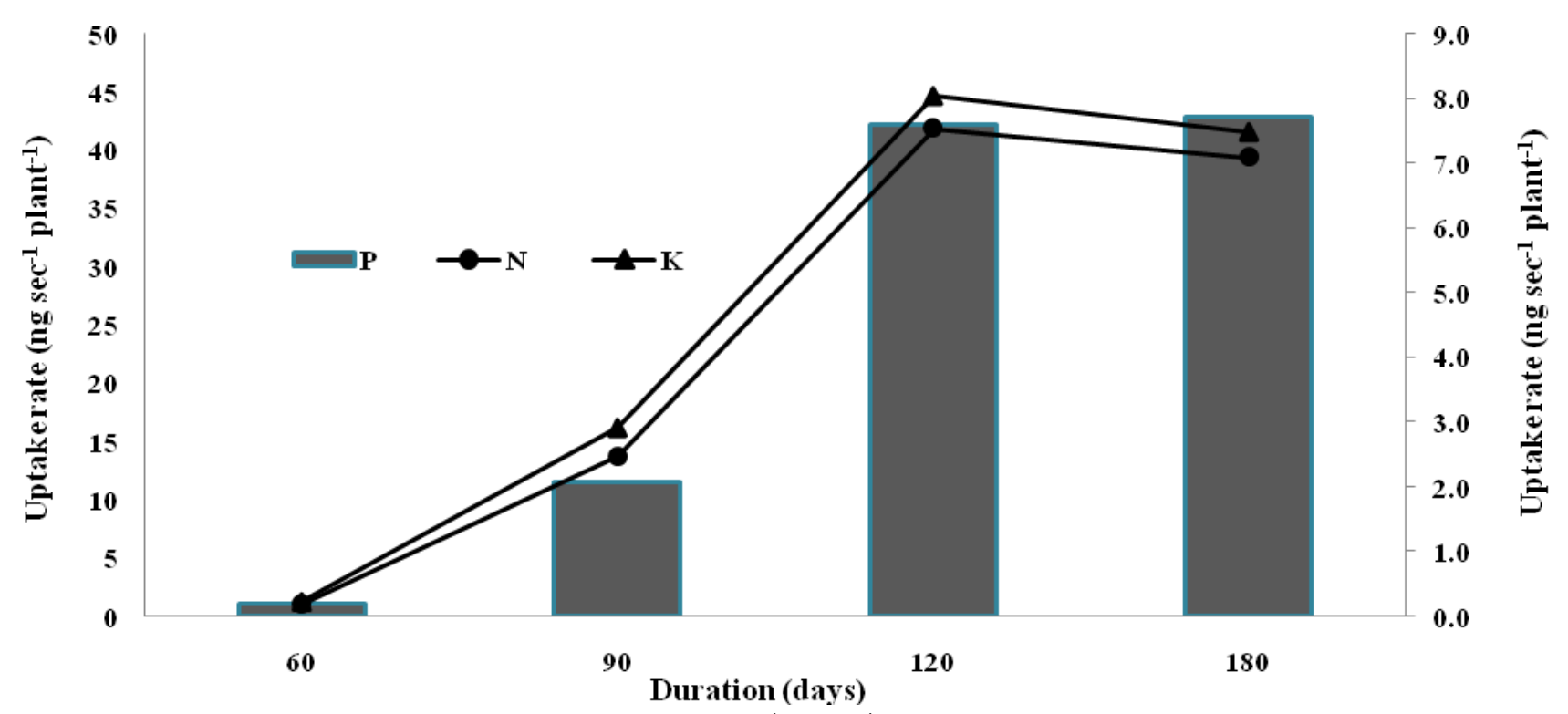

Fig. 6: $\mathrm{N}, \mathrm{P}$ and $\mathrm{K}$ uptake rate $\left(\mathrm{ng} \mathrm{sec} \mathrm{slant}^{-1}\right)$ in fennel on its growth intervals

In general, potassium uptake rate increased linearly with increase in time and doses of $\mathrm{N}$, however it was increased sharply at $120 \mathrm{~kg} \mathrm{~N}$ during 121-180 days (Fig. 5). Moreover, $\mathrm{K}$ uptake was lower at lower levels of $\mathrm{N}$ during 121-180 days in comparison to $91-120$ days. The activation of enzymes is a major, critically and important role of $\mathrm{K}^{+}$in plant for synthesis and protein metabolism in plant. The deficiency $K$ in higher plant is due to accumulation of amino acids and amides in the tissues. Hence, it acts as a precursor of protein synthesis reason by more uptake ofK with higher input of $\mathrm{N}$ and protein synthesis. Luxury consumption of $\mathrm{K}$ leads to higher content in plant and uptake too.

\section{Comparative uptake kineticsat various growth stages}

Overall uptake rate of $\mathrm{N}, \mathrm{P}$ and $\mathrm{K}$ was more with higher doses of $\mathrm{N}$ and duration/age of crop plants (Fig. 6). However, N and $\mathrm{K}$ uptake rate was highest at 91-120 days and reduced thereafter. Moreover, the uptake rate of $\mathrm{K}$ was

\section{REFERENCES}

Aishwath, O.P. (2004) Mineral nutrition and growth of Withaniasomnifera. Journalof Tropical Medicinal Plants (Malaysia) 5(1): 111- 118. higher than $\mathrm{N}$ and was least of $\mathrm{P}$. This might be due to fennel is a halophytic plant in nature and could withstand in saline condition by excessive accumulation of monovalent cations $\left(\mathrm{K}^{+}\right)$, hence, $\mathrm{K}$ uptake and rate was higher than $\mathrm{N}$ and $\mathrm{P}$. Whereas, $\mathrm{N}, \mathrm{P}$ and $\mathrm{K}$ uptake rate positively influenced by $\mathrm{N}$ input up to the age of 120 days of crop plants due to more active growth phase of crop during the period (120 days).

Therefore, it can be concluded from the results that higher doses of $\mathrm{N}$ and age of crop plants has negative relation for the $\mathrm{N}$ uptake, whereas $P$ uptake rate gave positive relation with doses of applied $\mathrm{N}$ and aging of crop plants. In contrast to $\mathrm{N}$ and $\mathrm{P}, \mathrm{K}$ uptake rate showed positive relation to $\mathrm{N}$ input and negative at highest levels of $\mathrm{N}$.

\section{ACKNOWLEDGEMENT}

Director ICAR-NRCSS, Ajmer is gratefully acknowledged for the facilities provided during study and assistance rendered by Mr. Prithviraj Meghwanshi during chemical analysis is also acknowledged.

Aishwath, O.P. (2017) Nutrients uptake pattern in some important cultivars of fennel under Typic Haplustepts for their management precisely and farm gate 
budgeting. International Journal of Seed Spices 7(2):19-25.

Aishwath, O.P., Singh, R., Jha, B.K., and Mehta R.S. (2015) Growth kinetics and yield of coriander under limed acid soils of eastern plateau hill regions. International Journal of Seed Spices 5(1):49-55.

Barros, L., Carvalho, A.M. and Ferreira, I.C.F.R. (2010) The nutritional composition of fennel (Foeniculum vulgare): Shoots, leaves, stems and inflorescences. LWT Food Science and Technology 43: 814818(doi:10.1016/j.Iwt.2010.01.010)

Chapman, H.D. and Pratt, P.F. (1962) Methods of analysisfor soil, plant and water. Division of Agricultural Science, University of California, California.

Cocharn, W.G. and Cox, G.M. 1987. Experimental designs, Second Edition, John Wiley and Sons, New York.

Daniel, P., Schachtman, Reid, R.J.,Ayling, S. M.(1998) Phosphorus Uptake by Plants. Soil to Cellin Plant physiology 116 (2): 447-53.

Demirel, S., Tuzen, M., Saracoglu, S., and Soylak, M. (2008) Evaluation of various digestion procedures for traceelement contents of some food materials. Journal HazardMater 152:1020-1026.
Divrikli, U., Horzum, N., Soylak, M. and Elci, L. (2006) Trace heavy metal contents of some spices andherbal plants from western Anatolia. InternationalJournal of Food Science and Technology 41:712716.

Jackson, M.L. (1973) Soil Chemical Analysis, Prentice.Hall of India, Pvt. Ltd., New Delhi.

Rai, S.K., Katiyar, R.S. and Singh, S.P. (2002) Effect of nitrogen and phosphorus on the growth and yield of Foeniculumvulgare on the sodic soil. Journal of Medicinal and Aromatic Plant Sciences 24(1): 6567.

Sharma, N. and Aishwath, O.P. (2018) Growth kinetics of fennel with nitrogen application in TypicHaplustepts. Annals of Plant and Soil Research 20:1-9.

Silberbush, M., and Lieth, J.H. (2004) Nitrogen and potassium uptake by greenhouse roses (Rosa hybrida) along successive flower- cut cycles. Scientia Horticulturae 101: 127-141.

Singh, V. and Garg, A.N. (2006) Availability of essential trace elements in Indian cereals, vegetables andspices using INAA and the contribution of spicesto daily dietary intake.Food Chemistry 94: 81-89. 